\title{
Divided society model and social cleavages in Japanese politics: No alignment by social class, but dealignment of rural-urban division
}

\author{
DAVID CHIAVACCI
}

\section{Abstract}

In recent years, Japan has been marked by fundamental changes. From the late 1990s onward, a new model of Japan as a divided society has replaced the former model of Japan as a general middle class society with a very high degree of equality regarding chances and outcome. Moreover, the national elections of 2007 and 2009 resulted in a historical defeat of the Liberal Democratic Party (LDP) and in a new government led by the Democratic Party Japan (DPJ). Using the framework of social cleavage theory, this paper analyses the relationship between these two changes in a historical perspective. It raises the questions of whether and how the new divided society model is connected to the recent change of power. Has the ascendance of the divided society model and its establishment as the dominant model and common sense played a role in the crushing defeat of the $L D P$ and the change in power in the two recent elections? The main argument is that postwar Japanese politics and over five decades of LDP dominance were marked by a social cleavage between urban and rural areas. While a social cleavage by social class never fully developed in Japanese politics, stable and strong support by rural voters was the main pillar on which the LDP's long success story was based. The new model of Japan as a divided society has played an important role in the change in power in the two recent elections. Although this new divided society model has not led to an alignment by social class - as one may have expected - it has resulted in a dealignment in the rural-urban division. The demise of the $L D P$ was primarily due to its recent electoral defeat in rural areas, where it had once been invincible.

Keywords: social cleavage theory; social inequality; social class; urbanrural division; general middle class model; divided society model; postwar Japanese politics. 


\section{Introduction}

Japan is known as one of the most earthquake-prone countries in the world. Still, political earthquakes were an unknown phenomenon in recent decades. Besides a short interlude of a few months in 1993-1994, the Liberal Democratic Party (LDP) pulled the strings as main government party since its foundation in 1955. This long stay in power made the LDP the most successful political party in all postwar democracies. However, the Upper House election of September 2007 and the Lower House election of August 2009 have resulted in a real political earthquake and change in government. For the first time since its foundation, the LDP has been ousted from power in national elections by the voters, and a new coalition government led by the Democratic Party Japan (DPJ) has gained strong majorities in both chambers.

This political paradigm shift has coincided with a new model of Japan regarding social inequality (Chiavacci 2008; Ishida and Slater 2009: 1-12). From the 1960s onward, Japan was increasingly regarded as a general middle class society (sōchüryū shakai) with an outstanding degree of social equality regarding outcome as well as chances (EPA 1964, 1974; Galtung 1971; Murakami 22 May 1977; Reischauer 1977: 170-175; Sawyer 1976: 14, 17; Vogel 1979: 120-121). According to this model and dominant self-description, Japanese society had in international comparison not only a very equal income distribution, but was also very open to social mobility thanks to its highly meritocratic education system. However, from the late 1990s onward, a new view of Japan as a society of increasing inequality and of wide social disparities in international comparison emerged in public and social science discussions (BSH 2000; CKH 2001; Tachibanaki 1998; Satō 2000). In recent years, this discourse has evolved into a new model of Japan as a divided society (kakusa shakai) that has become common knowledge and superseded the former model of Japan as a general middle class society (BSH 2006; Miura 2005; Yamada 2004). As main factors for increasing inequalities in the debates accompanying the new divided society model, the deregulation policies of the LDP, and particularly structural reforms during the leadership of former Prime Minister Koizumi Jun'ichiro from 2001 to 2006, have been fiercely criticized.

This paper tries to answer the questions of whether and how the divided society model and the change of power are connected. Has the ascendance of the divided society model and its establishment as the dominant model and common sense played a role in the crushing defeat of the LDP and the change in power in the two recent elections? In order to answer these questions, cleavage theory of political sociology will be used as a framework. The concept of social cleavage includes, according 
to its generally accepted definition (Bartolini and Mair 1990: 213-220), three elements: (i) division of society into groups along demographic or socioeconomic lines, (ii) collective identity and shared attitudes of such groups, and (iii) distinct organizational bases or forms of collective action of such groups. In a more general meaning, the term social cleavage is used for "durable patterns of political behavior linking social groups to political organizations" (Bornschier 2009: 3). In their seminal article that established cleavage theory, Lipset and Rokkan (1967) identified four social cleavages (workers-owners, rural-urban, state-church, as well as center-periphery) that had framed politics and party systems in Western democracies since the 1920s. The most influential among these four social cleavages was the division between working class, voting for the left, versus owners and middle class supporting the right. However, from the 1970s onward, unattached voters increased, new political issues arose and party systems started to change. Empirical research identified a decreasing salience of social class (or workers-owners cleavage) in party support and resulted in a still ongoing debate about a decline of social class (Knutsen 2007). These developments resulted in a re-conceptualization of cleavage theory and much more dynamic models. In recent years, it is processes of alignment and dealignment of social cleavages that are emphasized and studied (Bornschier 2009: 3-7; Deegan-Krause 2007: $550-552)$. This new research agenda is connected to the problem of structure and agency. Respectively and more concretely, how are social structures and their dominant perception translated into party systems and durable party support by certain social groups? Are political elites framing social cleavages by stressing certain issues in top-down processes and/or are shifts in social structures and new social movements in bottom-up processes shaping social cleavages?

These questions are addressed for the case of Japan in this paper by analyzing recent changes in the historical context of postwar politics. In section two, social cleavages marking the long period of LDP dominance and the role of the general middle class model in this LDP dominance are discussed. The new divided society model and its context are the topic of section three. Finally, in section four, possible changes in Japan's social cleavages due to the divided society model and their influences in the change in power from LDP to DPJ are studied. The analysis concentrates on the long-term shifts in social cleavages by social class and ruralurban division as the two most important social divisions in postwar Japanese politics. The main argument here is that the recent change in power is indeed strongly influenced by the new divided society model. However, it is not the result of an alignment of social cleavages by social class, but the result of a dealignment of the rural-urban division. Japanese politics have been marked by a rural-urban cleavage since the late 
1940s and a loss of importance of social class parallel to the ascendance of the general middle class model during the 1960s. Rural areas were the strongholds of the LDP and guaranteed its victories in national elections. However, a new discourse of rising regional disparities (chi'iki ka$k u s a)$ between economic centers and rural areas is embedded in the divided society model. The structural reforms under Koizumi and his predecessors are seen as the main reason for rural decline and have resulted in a fundamental weakening of the links between the LDP and its rural support groups and clientele. These structural and discursive shifts have been cleverly used by the DPJ, led by Ozawa Ichiro, for their landslide victories in rural Japan in the two recent elections.

\section{From societal conflicts to LDP hegemony}

\subsection{Societal conflicts in early postwar Japan}

The total defeat of Imperial Japan in the Pacific War and the following U.S.-led occupation was a turning point in the modern development of Japan (Chiavacci 2006a: 189-190). Early postwar Japan was marked by two interlinked societal conflicts. First, the quest for a leading position in the world system by the political elites and the subordination of Japan's population to this national goal as embodied in the slogan messhi hōko [self-sacrifice for the sake of state] was strongly challenged and no longer generally accepted. This delegitimization of the former national project resulted in a fundamental conflict between social forces for a new social contract and national project. Second, due to the fundamental political reforms by the occupation, newly founded political parties of the left, labor unions as well as farmer unions flourished and challenged the conservative establishment. While the left envisaged the nationalization of Japan's core industries, its conservative counterpart was fully endorsing capitalism and private ownership. This conflict between socialism and capitalism on the system level was also mirrored in struggles over the control of the workplace (Gordon 1993: 378-383). The labor movement envisaged secure employment and accident-free workplaces for workers. It wanted co-determination in corporate governance. Management stressed its own preeminence in business matters and the importance of productivity and rationalization as basis for the profitability of companies and economic growth. The climax of these two societal conflicts were the years 1959-1960 with the large Mi'ike strike and the mass demonstration against the renewal of the bilateral security treaty between Japan and the U.S. (Chiavacci 2006a: 191-192).

Concerning the national project, the party system in early postwar Japan was clearly marked by contradictory positions between conserva- 
tive and progressive parties. However, both sides were also marked by internal divisions and personal animosities. The conservative camp was divided into two main groups (Pyle 1992: 31-32). One group under the leadership of Yoshida Shigeru prioritized economic reconstruction instead of remilitarization and accepted political subordination under the U.S. This position became known as the Yoshida Doctrine. The other group, led by politicians such as Hatoyama Ichiro and Kishi Nobusuke, favored reestablishing full independence from the U.S. as soon as possible and regaining a political leadership position in the world system through a remilitarization of Japan. Progressive forces of the left favored a demilitarized and neutral Japan, in which equality and individual rights were the core of the national project instead of the rebuilding of national power. However, the left was even more strongly characterized by fragmentation and internal conflicts. It was only in 1955 that two large parties, the Japan Socialist Party (JSP) on the left and the LDP on the right, were established through the (re)unification of smaller parties.

During these years of political turmoil, a partial alignment occurred, but no full social cleavage according to social class emerged. The party system was clearly structured by class politics. Ideological differences according to class discourse marked the positions of the LDP and JSP, and their predecessors (Imada 1989: 140-142). Conservative parties promoted capitalism and private ownership, left-wing parties demanded socialism and nationalization. However, this demarcation in the party system did not develop into class patterns of party support. Instead of class affiliation, voting behavior correlated more strongly with the level of education and age. The support of the left was much higher among young and better educated voters. While farmers, self-employed merchants and manufacturers, as well as blue-collar workers in small and medium-sized enterprises (SME), were more likely to support the right, the majority of votes among blue-collar workers in large companies and white-collar workers went to the left (Masumi 1985: 355-357; Watanuki 1967: 448-456). The missing division of voting behavior by class was due to two interlinked factors. In public debates about the future path of Japan, ideological antagonism between capitalism and socialism was overshadowed by the conflict about a new national project and remilitarization. Accordingly, the dividing line in voting behavior was primarily between traditional-conservative values versus modern-progressive values rather than class consciousness (Watanuki 1967: 456-460). On an organizational level, the relatively strong support of the LDP and its predecessors among blue-collar workers of SMEs was primarily due to their relative weak unionization as well as the paternalistic employment practices of company owners. Class antagonism dominated party poli- 
tics, but union and political leaders of the left were not able to fully organize blue-collar workers.

In contrast to social class, in the rural-urban dimension a full social cleavage was institutionalized. From the late 1940s onwards, the rural areas became the stronghold of the LDP and its predecessors. They were able to gain the overwhelming support of farmers, who as the largest group of voters were crucial for the election successes of conservative parties in early postwar Japan. According to Watanuki (1967: 450), the voting behavior of farmers was due to the conservative values of the small family farmers and their firm integration into the social structures and ties of their villages. However, Babb (2005) shows convincingly in his analysis that the support of conservative parties among farmers cannot simply be attributed to traditional values, but is primarily the result of political processes. Although they had played a crucial role in the land reform of 1947, progressive politicians were unable to capture the support of farmers thereafter due to internal fragmentation and competition. While farmer unions declined in importance, agricultural cooperatives $(n \bar{o} k y \bar{o})$ proliferated rapidly after the passage of the Agricultural Cooperative Association Law in December 1947. They became rural grassroots organizations for winning elections in rural areas (Masumi 1985: 257-259). From the late 1940s onward, conservative politicians started to build and strengthen political ties with these cooperatives by increasing subsidies for agriculture and farmers. Through these organizational ties, they were able to establish their dominance in rural Japan in elections.

\subsection{Constitution and continuity of LDP hegemony}

Although the LDP won solid majorities in the first elections after its foundation in 1955, the existing voting patterns did not put the LDP in a position of dominance in the long-term. In view of educational expansion as well as industrialization and urbanization, it was generally predicted that the JSP would enlarge its voting share and overtake the LDP in a few years (Naoi and Tokoyasu 1990: 149-153). Even LDP politicians predicted at the time that the JSP would almost inevitably surpass the LDP in the early 1970s (Ishida 1963). However, this scenario never materialized. If we exclude the short intermezzo of less than a year in the early 1990s, the LDP remained solidly in power for over five decades up to 2009.

This political continuity was due to the establishment of shared growth as the new national project and social contract of postwar Japan (Chiavacci 2006a: 191-192). In 1959-1960, the climax of the social and political conflicts of the early postwar era had brought the Japanese democ- 
racy near the abyss. Then Prime Minister Kishi Nobusuke played an important role in the escalation of these political conflicts with his uncompromising policy style. Soon after the renewal of the security treaty, Kishi was forced to step down and was replaced by Ikeda Hayato as Prime Minister. Under Ikeda's leadership the LDP moved away from sensitive political issues like remilitarization or regaining status as a world power. It focused its policy on shared economic growth. The renaming of a growth plan for doubling the GNP, which the conservative government had already developed in the late 1950s, into the "National Income Doubling Plan" (Kokumin shotoku baizō keikaku) under Ikeda symbolizes this paradigmatic change and reinvented the LDP as a champion of shared growth. Economic growth was no longer a goal for reestablishing national grandeur, but the whole population was to participate and profit from economic growth and increasing wealth. The Yoshida Doctrine of prioritizing economic growth was socially anchored under Prime Minister Ikeda by proclaiming a growth pact between the conservative establishment and the general population. By sidelining questions of militarization and establishing the new social contract, the LDP became more attractive for higher educated people and was able to increase its support among urban white-collar workers (Naoi and Tokoyasu 1990: 151). Moreover, class struggle also diminished in importance during these years. From 1960 to 1973, Japan achieved not only unprecedented growth, but the general population experienced a tremendous increase in purchasing power, a flourishing of mass consumerism and an increasing social upward mobility (Imada 1989: 143-145). In other words, the LDP government kept its promise that the fruits of hard labor and economic growth would be shared with the general population. This increasing social upgrading and social fluidity resulted in a weakening of class antagonism and workplace struggles. During the 1960s, the Japanese employment model was established as a compromise between workers and management. A new, but still also very fuzzy societal model of Japan as a general middle class society emerged and started to resonate in the population (Asahi Shimbun 27 June 1967; Chiavacci 2008: 10-13; EPA 1964; Imada 1999: 3; Yomiuri Shimbun 28 July 1964).

The failure of the JSP to adapt to these new developments was a second crucial factor for the constitution and continuity of LDP hegemony. Despite diminishing class antagonism, the JSP adhered to its socialist positions and did not move ideologically to a more centrist position (Imada 1989: 144; Kohno 2001: 68). In 1964, the JSP adopted "A Road to Socialism in Japan" (Nihon ni okeru shakaishugi e no michi) as the official party line, which envisioned peaceful socialist revolution as inevitable for Japan and as the historic mission of the JSP. However, in view of Japan's economic success story and the rising lifestyle of the 
overwhelming majority of the population, socialization of the economy was an ideal shared by a rapidly diminishing minority. While the new social contract based on capitalism had been established, the JSP still stressed socialism. The official party line of socialist revolution, which had made the JSP not a viable alternative to the LDP, was only abolished as late as 1986. The dominance of left-wing positions within the JSP furthermore resulted in secessions and formations of new, more centrist parties in 1960 and 1977. Together with the appearance of the centrist Komeito $^{1}$, this led to a further weakening of the JSP, resulting in significantly falling support rates and election results for the JSP from the second half of the 1960s onward (Kawato et al. 2001: 166; Kohno 2001: 69; Naoi and Tokoyasu 1990: 151).

Still, despite the reinvention of the LDP as the champion of shared growth, and the failure of the JSP to adapt to a changing societal environment, the firm support base of the LDP also declined during the 1960s as nonpartisan voters strongly increased (Kawato et al. 2001: 166). However, in the 1970s the LDP made a comeback. It was able to increase again its support base and voting share by introducing new policy programs concerning social welfare and environmental issues that made it more attractive to urban voters (Murakami 1984: 243-244). During the 1970s and 1980s, the general middle class model was further enhanced (Chiavacci 2008: 13-17; Hara 2008), which made the class-struggle position of the JSP even more outdated and reinforced the LDP's image as the only viable option for government. During the 1970s, the LDP strengthened also its power base in the countryside by increasing public works in rural areas. From the 1970s onward, public works expenditure as a share of GNP was much higher in Japan than in Western advanced economies (Higuchi 2008: 13-14). This pork barrel policy for the countryside marked the redistribution patterns by the state in Japan. In most Western democracies, state intervention leads to redistribution between social classes through welfare programs that are financed by progressive income and wealth taxation. But in Japan, urban tax money is used for infrastructure programs in the countryside, leading to inter-regional redistribution patterns from economic centers to rural areas (DeWit and Steinmo 2002). The LDP government developed also a very comprehensive support system for farmers through financial aid and protection against agricultural imports from abroad (Mulgan 2005). Through these policies, the LDP was able to reinforce its clientele networks in the countryside, especially among voters from farming and construction businesses (Miyano 2000: 58). The urban-rural cleavage was thus even further strengthened.

Overall, these developments gave rise to a "dual party system" in Japan (Scheiner 2006: 5). While the countryside was dominated by the LDP, 
the urban areas were marked by party competition. Still, the LDP was able to retain its power because the election system had a strong bias towards the countryside. ${ }^{2}$ The voter to seat ratio between rural and urban areas was about $3: 1$ at the time of the election system reform in 1993, which reduced it to about 2:1 (Krauss and Pekkanen 2008: 22). Thanks to its stronghold in rural areas, the LDP survived recurring scandals of political corruption. Even the short interlude of disempowerment of the LDP in 1993-1994 was not due to lost elections, but to secessions of several LDP factions which formed new parties.

After the political turmoil of the first half of the 1990s, which resulted in the nearly complete decline of the JSP, the DPJ was founded in 1996. Yet even this major new opposition party with a much more moderate position seemed unable to challenge the LDP's grasp on power. On the one hand, the LDP still dominated the electoral districts in rural areas thanks to its redistributive policies and clientele networks. On the other hand, the LDP still represented the most reliable option to generate economic growth, which made it attractive to urban voters. The continuous hegemony of the LDP was based on two pillars: the LDP as a rural party and the LDP as a shared growth party. From a perspective of social cleavages, Japanese politics was until very recently marked by a full urban-rural cleavage. The division by social class, which had never developed into a full social cleavage, eroded step by step from the 1960s onward.

\section{From general middle class society to divided society}

\subsection{End of shared growth and new perception of social inequalities}

Up to the early 1990s, Japan was a model of growth. After the end of the Golden Era of capitalism in the 1970s, most advanced economies experienced economic problems with recurrent recessions, high inflation, and increasing unemployment. In contrast, Japan returned after a harsh but short economic recession in 1973 to a stable path of economic growth. In view of near full-employment, an industrial switch to hightech products and a growing trade surplus, Japan seemed an unstoppable economic success story. In the 1980s, it was even debated whether Japan might overtake the U.S. and establish a Pax Nipponica (Vogel 1986).

However, in the early 1990s the economic success story of Japan came to a sudden end. After the Plaza Agreement of 1985, a very low prime rate policy had caused speculative bubbles in real estate and stock market that burst in the early 1990s. Japan entered into a period of economic stagnation, which is known as the "lost decade" (ushinawareta jünen). In the early years of economic stagnation, the state tried to stimulate the 
economy through a Keynesian growth policy, but the financial crisis of 1997 led to a questioning of this approach. An increasing number of pundits and politicians regarded the economic stagnation not as a result of an economic cycle that had been magnified by speculation and investment excesses in the late 1980s, but attributed the economic malaise instead to structural malfunctions because of a dual economic structure between competitive export industries and protected domestic sectors. A neoliberal perspective of structural reforms following the example of the market-oriented and successful U.S.-economy became increasingly dominant in public discussions and policy-making circles (KSK 1999; Nakatani 1996). As part of this neoliberal discourse of structural reforms and a renewal of Japan's economy, "evil equality" (akubyōdō) became a buzzword. Neoliberal exponents described the "overemphasis" on social equality in Japan as a major inhibitor to economic recovery. Iwao Nakatani, an influential economist and member of several governmental reform committees, argued:

The Japanese must realize the need to replace the postwar emphasis on egalitarianism with a more balanced vision recognizing the importance of fair competition for the sake of increasing efficiency. That is, Japan cannot be efficient and remain competitive in the world market if it continues to be preoccupied with the equality of outcomes seen in the overemphasis on the distribution of income. Egalitarianism, which long helped to increase demand, strengthen the spirit of cooperation among employees, and maintain the social order, has become a drag on creativity, competitive élan, and the desire to work and excel. (Nakatani 1997: 400)

This new discourse implied a turning away of part of the conservative establishment from Japan's societal model as a general middle class society towards a more liberal and unequal model. In this new zeitgeist, empirical research by Tachibanaki (1998) on income distribution and Sato (2000) on social mobility triggered a fierce public discussion on rising inequalities. Tachibanaki (1998: 4-6) argued in his study that income distribution in Japan had become much more unequal and that Japan had the most unequal income distribution among advanced economies, including the United States Sato (2000: 51-63) analyzed changes in social mobility and reached the conclusion that the social stratum of leading white-collar employees, who he called the "knowledge elite" (chishiki erīto), had become increasingly socially closed. According to him, the chances to attain such a leading position had decreased sharply in recent years for those not born into the knowledge elite. In other words, social status was no longer achieved, but inherited. 
Both studies have been fiercely criticized because of methodological problems and contradicted by other empirical studies (Hashimoto 2003: 125-127; Ishida 2008; Ōtake 2000: 3-4; Seiyama 2000). Overall, macro indicators and empirical studies do not support a paradigmatic change in Japan regarding social equality in chances and outcome in recent years. Neither was Japan an exceptionally equal society from the 1960s onward nor has it gone through a fundamental transformation into a socially divided society (for details, see Chiavacci 2006b, 2008). Still, these two studies had a strong impact in Japan's public discussions. Their findings suggested that neoliberal calls for more inequality were not only rhetoric, but had actually already become reality. The resonance of these two studies in public discussions can be explained by the fact that their findings about economic and social changes on the macro level matched new trends in the daily lives of the population on the micro level. Parallel to the high-growth period of the 1960s, a large majority of the population had experienced upward social mobility and increasing purchasing power. This trend had not been reversed with the end of high growth. On the contrary, from the 1970s onwards social upgrading continued, as the upper white-collar class strongly expanded and the idealized life course of secure employment and an internal career in a large corporation became realizable for an increasing share of the male population (and their wives and families) (Chiavacci 2008: 15-17). However, in the late 1990s social upgrading came to a sudden end. Between 1997 and 2003, average monthly household income, which had increased continuously for decades, decreased by over 10 percent (MIC 2005). Unemployment and atypical employment strongly expanded, especially among young workers. Even university graduates had a hard time finding good and attractive jobs. And as the bankruptcy of large companies like Yama'ichi Securities in 1997 demonstrated, even those who found a job in large companies could no longer count on employment and career security.

At first the controversy concentrated primarily on rising inequalities among white-collar employees as the core of the general middle class model, the increasing importance of social background for educational attainments, and the growing social closure of the elites (BSH 2000; CKH 2001). However, from about 2003 onward, the debate started to widen. Atypical employment and poverty became central topics in public discussions. A polarization of Japanese society into those who were still fully socially integrated and an increasing group of socially excluded persons was identified. The bestsellers of Miura (2005) and Yamada (2004) were especially influential in forming this new discourse of Japanese society. The new model was summed up into a description of Japan as a "divided society" (kakusa shakai), a term that derived from Yamada 


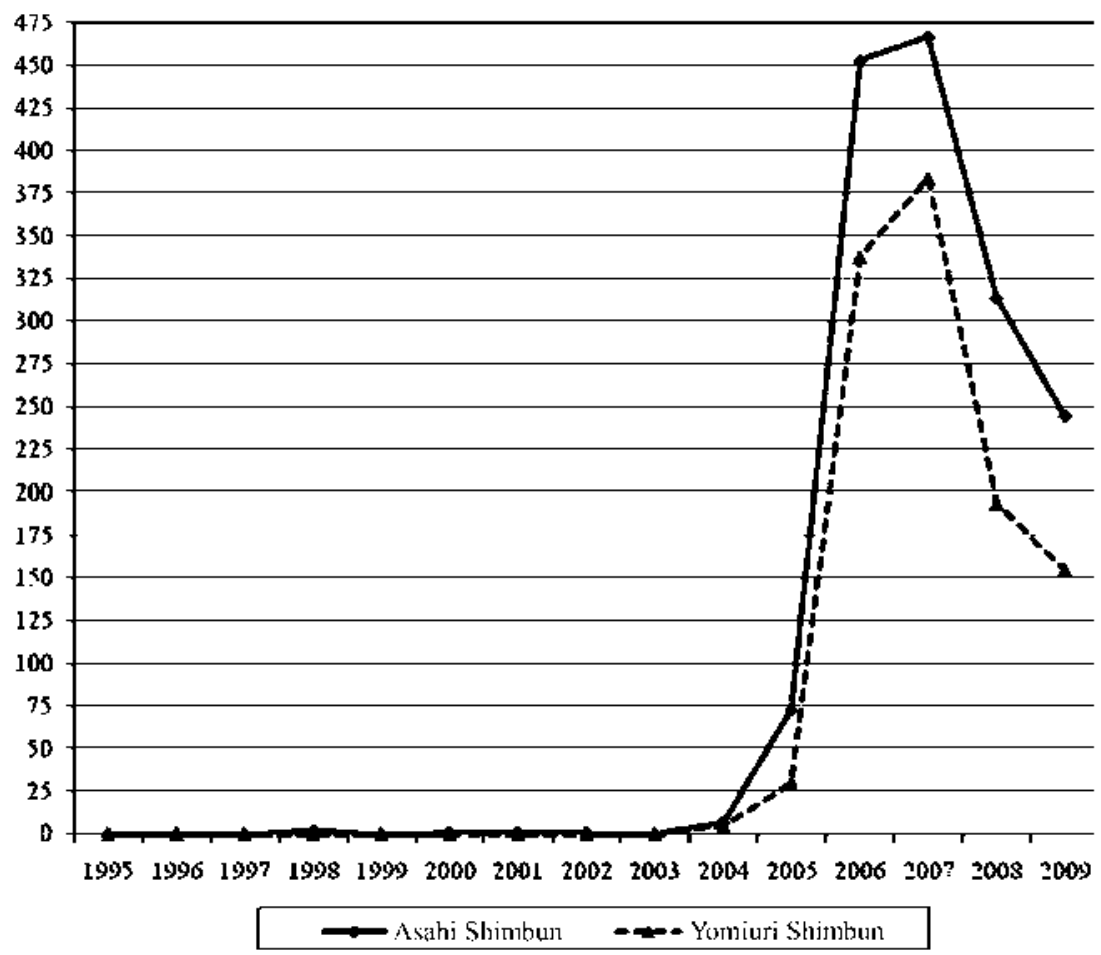

Figure 1. Number of articles in Asahi Shimbun and Yomiuri Shimbun containing the term kakusa shakai [divided society], 1995-2009.

Source: Own full text research in electronic databases "Kikuzo II Visual" (Asahi Shimbun) and "Yomidasu Rekishitan" (Yomiuri Shimbun).

(2004). This new societal model replaced the general middle class model as the dominant perspective (BSH 2006). The impact is comparable to that of a tidal wave in public debate, visible in the two largest daily newspapers Asahi Shimbun and Yomiuri Shimbun, (see Figure 1). While the term "divided society" was only used in a few articles referring to the U.S. up to 2004, out of nowhere it truly overflowed into the public discourse and the mass media afterwards. In 2006 and 2007 the term "divided society" appeared even in the conservative, rather LDP-friendly Yomiuri Shimbun on average every day in an article. Although the debate has receded somewhat in the last two years, still on average every second day an article containing the term "divided society" is published in both newspapers.

A second shock resulted in this enlargement, intensification and consolidation of the discussions on rising social inequalities into a new 
model of Japan as a divided society. From 2003 up to autumn 2008, the Japanese economy returned to a steady growth path, and experienced the longest economic expansion in postwar history. However, this economic growth did not translate into higher incomes or a full turnaround in the labor market. Although company profits increased strongly, average household income continued to stagnate (MIC 2009: 147). And although unemployment fell, atypical employment continued to increase. Over a third of all workers were in atypical employment in 2008 (MIC 2009: 138 and 140). In other words, the economic recovery did not lead to a recovery of the former social order. On the contrary, large parts of the population saw their own lives decoupled from economic growth. They found themselves excluded from the renewed economic success story. The general middle class model and shared growth were not reestablished through renewed economic growth.

\subsection{Regional disparities}

During its reframing from 2004 onwards, the new model of Japan as divided was further enlarged, as rising regional inequalities between urban centers and rural areas were linked into the model. Regional disparities and their growth also became a primetime topic in the Japanese mass media (Elis and Lützeler 2008: 15-16). This trend is clearly identifiable in the number of articles published in the Asahi Shimbun and Yomiuri Shimbun containing the term "regional disparities" (chi'iki kakusa) between 1985 and 2009 (see Figure 2). In contrast to the new concept of divided society, regional disparities were already earlier a topic in public debate. This discourse of regional disparities was of importance as it legitimized the redistributive policy from urban centers to the countryside. Still, from the later 1990 s onward, the number of articles mentioning regional disparities started to increase. In parallel to the boom in the topic of divided society in public discourse in 2006 and 2007, also the number of articles on regional disparities skyrocketed.

The background of this new level of debate about regional disparities is a decoupling of economic growth from regional development. In earlier periods, economic recovery spread to the countryside with a time lag of about one year, but during the last economic boom from 2003 to 2008 in many rural areas no significant economic improvement occurred (Higuchi 2008: 5-6). Large parts of the population in general and especially rural populations saw themselves excluded from the return to economic growth.

Overall, the self-view and model of Japan concerning social inequality has been inverted in recent years. The general middle class model has been superseded by a new model of Japan as a divided society. From a 


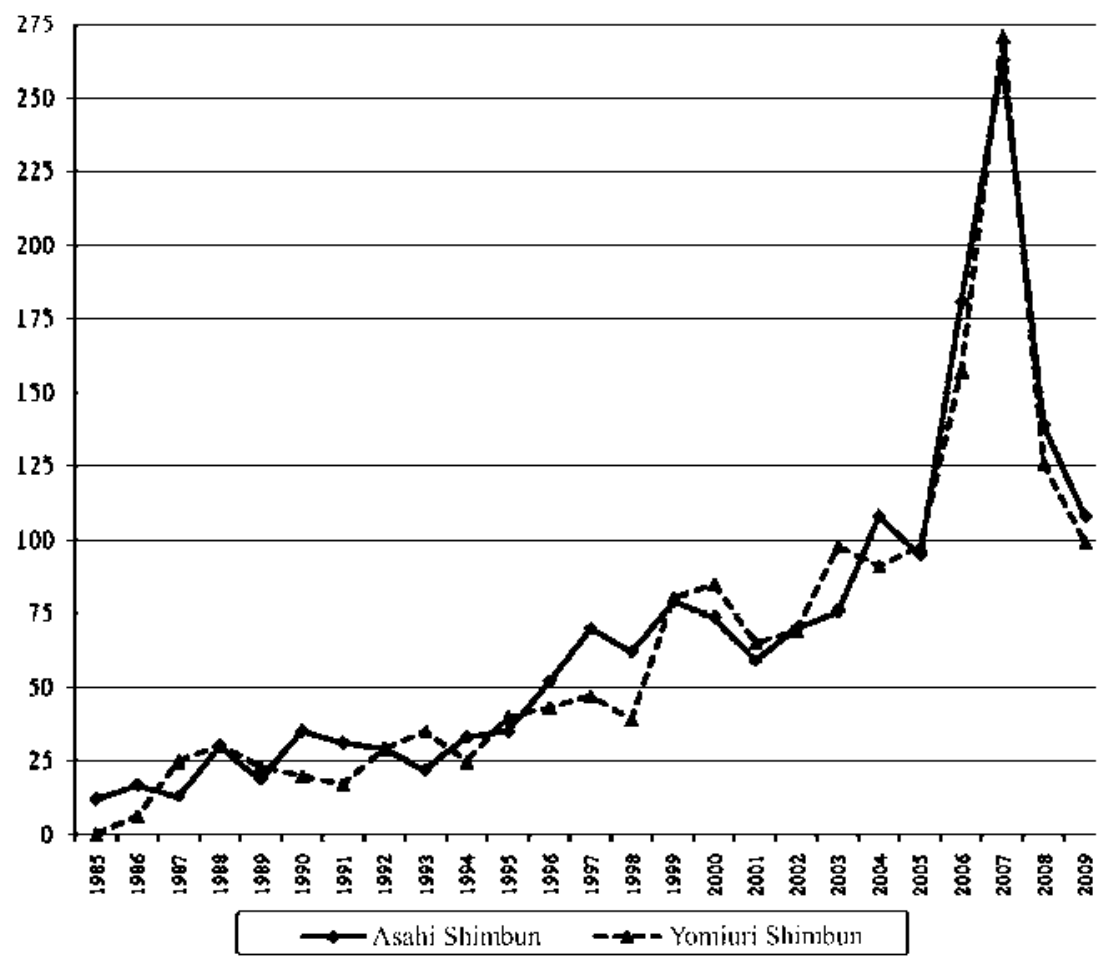

Figure 2. Number of articles in Asahi Shimbun and Yomiuiri Shimbun containing the term chi'iki kakusa [regional disparities], 1985-2009.

Source: Own full text research in electronic databases "Kikuzō II Visual" (Asahi Shimbun) and "Yomidasu Rekishitan" (Yomiuri Shimbun).

political perspective, the divided society model is of crucial importance as it implies an abandonment of shared growth and an exclusion of rural areas. Hence, the very two pillars on which the power of the LDP was based have been dismantled in recent years. This raises the question of whether these changes have influenced social cleavage structures and the voting behavior of the population?

\section{Regime change: Demise of the LDP and rise of the DPJ}

\subsection{Lower house election 2005: Koizumi's triumph}

In April 2001, Koizumi Jun'ichiro was elected president of the LDP and Prime Minister of Japan. He endorsed a structural view of Japan's lost decade of economic stagnation and started an agenda of neoliberal re- 
forms under the motto "no growth without reforms" (kaikaku nakushite seichō nashi). Japan was to be brought back to a path of growth through privatization, promotion of competition, and political decentralization (Kaihara 2008: 395-399). Before becoming Prime Minister, Koizumi was considered a maverick and somehow an outsider in the LDP. As Prime Minister, he vowed to press through reforms against all resistance, including from inside the LDP. Because of his outspoken personality and his image as an outsider to the establishment, he enjoyed high support rates among the population. It was hoped that he would be able to turn around Japan's development after a decade of economic stagnation.

One of the centerpieces of Koizumi's structural reforms was postal privatization. Opponents of postal privatization feared that it would only lead to the closure of post offices, diminished public service and increased unemployment. Koizumi and the supporters of a postal privatization claimed, however, that it would allow a more efficient use of the huge deposits in postal savings accounts and help economic recovery. In 2005, the post privatization bill passed the Lower House, but a number of LDP parliamentarians, together with the opposition parties, voted against the bill. Subsequently the bill was rejected in the Upper House by the votes of parliamentarians of opposition parties as well as a number of defecting LDP members. Koizumi used his power as Prime Minister and dissolved the Lower House and called snap elections. ${ }^{3}$ In an unprecedented move Koizumi expelled the defecting LDP parliamentarians of the Lower House from the party and posted rival candidates in their electoral districts, dubbed "assassin candidates" by the mass media. Koizumi had already been popular among the population due to his outspoken style and image, but this bold move made his support rate surge. The elections of September 2005 were primarily seen as a referendum pro or contra postal privatization. Koizumi had not only called a snap election, but was also able to set the agenda, as mass media coverage concentrated on postal privatization and the "assassin candidates". The policy proposals of the DPJ and other opposition parties were sidelined in public discussions.

The 2005 Lower House election ended in a triumph for Koizumi. The LDP not only won, but it achieved its second best result in Lower House elections of its entire history. The display of leadership and will to push through reforms even against internal party opposition made Koizumi and "his" LDP popular among unattached voters of urban areas. Particularly younger voters in their 20s and 30s were attracted by Koizumi's action. Among them the support for the LDP increased by more than 15 percent shortly after the dissolution of the Lower House and the naming of the "assassin candidates" (Maeda 2006). Still, closer analysis of the election results show that the shift of seats from the DPJ to the 
LDP was much larger than the LDP's actual gains in votes. ${ }^{4}$ Moreover, the LDP under Koizumi was able to attract new votes from unattached, urban voters, but already in the 2005 Lower House elections the downside of a policy of structural reforms was visible. Support from the countryside as the old stronghold of the LDP had decreased (Mori 2008: 4852). The LDP had gained in the 2005 elections thanks to new support in urban centers, but it started to lose support among its old clientele groups of rural areas (see also Yoneda 2008: 138-139). Postal privatization was primarily seen negatively in the countryside as it would lead to the closure of local post offices and, hence, the loss of local jobs as well as an erosion of local communities. While many voters and especially young voters believed that Koizumi would bring Japan finally back on a growth path by taking on the establishment, the urban-rural cleavage was already weakening in the 2005 elections.

\subsection{Politicization of the debate on social inequality}

The election result of 2005 led to a politicization of the debate on social inequality. The central question in public debates was no longer whether Japanese society had become more unequal, but if Koizumi and his structural reforms were responsible for it. In view of the sudden support of Koizumi among young voters, commentators and public intellectuals such as Kaneko Masaru (27 September 2005) started to ask why precisely young people who had to shoulder the brunt of increasing inequality and de-standardization of employment voted for Koizumi and his neoliberal reforms. Did the structural reforms really lead to a social underclass without aspirations, as predicted by Yamada (2004) and especially Miura (2005), which had voted against their own interests, because they had let themselves be tricked by the mass media image of Koizumi as a ruthless reformer who would also take on the establishment? The arrest of Horie Takafumi in January 2006 on suspicion of securities fraud and money laundering further heated up the debate. As a highly successful businessman he represented a group of rich, young entrepreneurs that symbolized a new, more liberal era of American-style capitalism in contrast to the old business establishment in Japan. Horie had been one of Koizumi's "assassin candidates" in the 2005 Lower House election. Already before his (unsuccessful) candidacy, he had become a media star through his extraordinary dress and outspoken communication style. His arrest gave Koizumi's critics ammunition in their claim that Koizumi and his structural reforms had caused a collapse of the social fabric, by leading to a class of ruthless rich parvenus without a social conscience and an underclass of socially excluded and demoralized people living in poverty. Moreover, the decrease of public work expendi- 
tures under the Koizumi cabinet was held accountable for rising disparities between urban centers and rural areas (Kaihara 2008: 400-401).

When the OECD (2006) identified increasing inequality and rising poverty in their yearly report on the Japanese economy as a serious problem for Japan, the divided society model gained scientific credibility by a "neutral", namely foreign organization that enjoyed high recognition in Japan. Moreover, reports such as one by Sano (2006) about underprivileged city areas and the lot of children from poor families in Tokyo were impressive accounts of those left behind by the structural reforms, giving discussions about social inequality a qualitative perspective - beyond pure statistical data. In the Japanese parliament, not only members of opposition parties, but even LDP politicians criticized Koizumi and his structural reforms in view of rising inequalities (Asahi Shimbun 27 January 2006; The Daily Yomiuri 27 January 2006). Koizumi and his administration were on the defensive and published several reports contradicting their critics in Japan and abroad (CAO 2006a; CAO 2006b: 256-281; Ōta 2006).

Were Koizumi and his neoliberal reform agenda really responsible for rising inequalities and social divisions? As already described above, it has to be stressed that arguments about an end of the middle class and the nascence of a divided society are widely overblown. The resonance of the divided society model is primarily due to the sudden end of general social upgrading that has fundamentally altered the perception of social inequalities. Moreover, it should not be forgotten that there is a time lag between structural reforms and their impact on a society. As in the case of the economic recovery in 2003 (Kaihara 2008: 399), increasing inequality in recent years cannot simply be causally attributed to structural reforms during the Koizumi administration. Moreover, as in the case of postal privatization, Koizumi's structural reforms were often watered down and delayed by opposition, especially from within the LDP. In this context, it is rather ironic that the DPJ was, before Koizumi's ascendance, more pro-deregulation than the LDP (Schoppa 2001). The DPJ supported for example postal privatization, but rejected Koizumi's bill as not comprehensive enough. However, it also has to be noted that macro indicators and empirical studies clearly show moderately rising inequalities in Japan in recent decades, especially concerning income distribution and regional disparities. Rising income inequality is a general trend in most advanced economies in recent years and the rise is relatively small in Japan in international comparison (Burniaux et al. 1998; Förster and D'Ércole 2005). In addition, studies identify changes in the age structures of the population and in the composition of households as main factors for the increasing income inequality per household in Japan (Funaoka 2001; Ōtake 2005). Still, deregulations of the labor mar- 
ket by the Koizumi administration were an important factor for the rising number of atypical workers with lower pay and less social security coverage. If not reversed, rising atypical employment will in the long term lead to much more significant increases in income inequality. Moreover, the rising number of atypical workers was a symbol in public debates that shared growth was not restored by the Koizumi administration.

Regarding regional disparities, reforms of the Koizumi cabinet and especially the cutbacks in public works contributed significantly to increasing inequalities between rural and urban areas. The total volume of public works decreased over 50 percent from 14.9 trillion yen in 1998 to 6.9 trillion yen in 2007 (Higuchi 2008: 13-16; JILPT 2008: 7-8). Already LDP-led administrations before Koizumi had implemented cutbacks in public works as this level of expenditures was regarded as unsustainable in view of the large budget deficit of the central government. Still, cutbacks were further pushed on during the Koizumi administration and hit rural areas where the importance of public works had strongly increased during the 1990s. For example, the number of construction workers fell sharply in parallel with the decline of public works (Higuchi 2008: 13-18). Moreover, the three large decentralization reforms (sanmi ittai kaikaku) ${ }^{5}$ realized by the Koizumi administration have also resulted in more regional disparities because economically weaker communities had to shoulder a loss of income (Elis and Lützeler 2008: 23-24; Hüstebeck 2009: 47-48).

\subsection{Upper house election 2007 and lower house election 2009: LDP's crash}

In several large surveys conducted in 2006, two thirds or more of the respondents perceived inequalities as increasing in Japan in recent years (CAO 2006b: 323). The main opposition DPJ under the new leadership of Ozawa Ichiro picked up the issue of divided society and presented itself no longer as advocate of truly comprehensive structural reforms, but as the "renovator" of an equal society - including rural areas. The new model of Japan as divided society and its politicization gained such momentum that it could no longer be ignored by the LDP. In the internal election of a new LDP president and Prime Minister after Koizumi's resignation in September 2006, all the candidates presented ideas for new policies against rising inequalities (The Daily Yomiuri 3 September 2006). Although he was a clear supporter of structural reforms, Abe Shinzo, the new Prime Minister, pledged to introduce policies that would give everybody a second chance in life. Still, his main policy agenda was to finish the project of his grandfather Kishi Nobusuke, namely to 
reestablish political nationalism as a national project through the revision of the postwar constitution and other policies. However, Abe was not able to gain wide public support for his political agenda and came increasingly under pressure to address the rising inequalities. In view of the upcoming election, his administration started to hastily draft a policy to tackle these issues (Murao and Kurokawa 20 February 2007). Moreover, the LDP shelved a bill that would have allowed companies to treat also part of the normal white-collar workers like managers by exempting them from overtime payment. The deliberation of this bill had received a lot of coverage in the mass media and was criticized as further proof that the LDP and business leaders were no longer ready to share the fruits of growth with the general population.

Still, the Upper House elections in July 2007 ended in a landslide victory for the DPJ, in which the party gained a clear majority. Apart from the issue of rising social and regional inequalities, the LDP and the Abe administration were further strained by several scandals, such as the loss of records for millions of payments in the national pension system. In comparison to 2005, the percentage of votes for the LDP did not only fall in urban areas, but its defeat by the DPJ in rural areas was crucial for the overall result (Krauss and Pekkanen 2008: 35-36). The analysis of Imai and Kabashima (2008) shows that in the 2007 Upper House elections the LDP in particular lost the support of farmers and construction workers in rural areas, who had been negatively affected by structural reforms.

The government coalition of LDP and New Komeitō was still able to govern with its two-thirds majority in the Lower House, which is the more important chamber of the parliament. Although Abe first pledged after the Upper House defeat to stay on, he later resigned. His successor Fukuda Yasuo tried to rebuild LDP support in the countryside by introducing new aid policies for small family farms after the Abe administration had pushed for structural reforms in agriculture and a restructuring of farms into large units. However, Fukuda, whose cabinet was confronted with a very low support rate among the population, resigned suddenly as Prime Minister after about a year, clearing the way for Asō Tarō as his successor. The LDP hoped that Asō would be able to show leadership and give the party new credibility in view of the upcoming Lower House elections in 2009. Still, his term as Prime Minister was marked by recurrent gaffes and falling support in the population. Moreover, the Japanese economy was hard hit by the financial and economic crisis of autumn 2008, leading to a sharp drop in exports and triggering the deepest recession in postwar history. The U.S. economy - as origin of this worldwide economic crisis - could hardly any longer be regarded as a model of economic success that should be emulated. Hence, a neo- 
liberal reform agenda following the example of a free-market economic order, like in the U.S., lost its power of persuasion. The Aso administration started a wavering course pro and contra structural reforms, which led to fierce LDP-internal criticism from supporters of structural reforms. Meanwhile, Ozawa had to step down as DPJ president due to a corruption scandal, but the DPJ policy platform for the upcoming elections still bore Ozawa's signature. It included among other promises income support for farmers, reversing the deregulation of the labor market, and raising the minimum wage to 1,000 yen. Hatoyama Yukio as the new top candidate of the DPJ pledged publicly to turn away from unrestrained market fundamentalism and to protect the livelihoods of the Japanese population (Hatoyama 2009).

The outcome of the Lower House election in August 2009 was again a demolishing defeat for the LDP. Like it had done in the Upper House election two years before, the DPJ was not only able to reestablish itself as the strongest party in urban centers, but also to win most rural districts, which had been strongholds of LDP support since the late 1940s. The urban-rural cleavage that had marked Japanese politics in favor of the LDP has been dealigned. In the 2007 and 2009 elections, the LDP was for the first time in its history ousted from government by the vote of the people as sovereign. Hatoyama became the $93^{\text {rd }}$ Prime Minister and headed a DPJ-led government coalition.

The new model of Japan as divided society marked by social inequalities and regional disparities has played a crucial role in the crushing defeat of the LDP by the DPJ in the two recent elections. It has also resulted in a partial change in the social cleavages of Japanese politics. While no new alignment regarding social class has emerged in social cleavages, a dealignment of the rural-urban division has occurred. In contrast to the clear demarcation between JSP and LDP and the clear class character of politics in the early postwar era, the ideological differences between DPJ and LDP are much less definite. Although the DPJ is overall to the left of the LDP, a considerable ideological overlap exists between the two major parties (Murakami 2009: 35-45; Steel 2008: 8487). Voting behavior is also not clearly divided by ideology, as representative surveys of the Association for the Promotion of Fair Elections (Akarui Senkyo Suishin Kyōkai) at the time of the elections in 2005 and 2007 show (see Table 1). While Koizumi's LDP was able to gain a significant share of votes from progressive voters in 2005, Ozawa's DPJ captured not only more votes among centrists, but also among moderately conservative voters. Today, success in national elections primarily depends on the parties' and the party leaders' abilities in agenda-setting and powers of persuasion rather than ideological positions. 
Table 1. Voting for DPJ and LDP by ideological self-assessment, 2005 and 2007.

\begin{tabular}{lccllc}
\hline & \multicolumn{2}{c}{ Lower House election 2005 } & & \multicolumn{2}{l}{ Upper House election 2007 } \\
\cline { 2 - 3 } \cline { 5 - 6 } \cline { 5 - 6 } & DPJ & LDP & & DPJ & LDP \\
\hline Conservative & $6.0 \%$ & $77.6 \%$ & & $16.9 \%$ & $52.9 \%$ \\
Moderately conservative & $20.6 \%$ & $53.8 \%$ & & $34.5 \%$ & $32.5 \%$ \\
Center & $28.9 \%$ & $36.5 \%$ & & $35.4 \%$ & $17.2 \%$ \\
Moderately progressive & $42.8 \%$ & $23.3 \%$ & & $51.6 \%$ & $7.9 \%$ \\
Progressive & $36.6 \%$ & $26.8 \%$ & & $48.4 \%$ & $1.6 \%$ \\
Don't know / No answer & $35.2 \%$ & $9.0 \%$ & & $17.5 \%$ & $21.0 \%$ \\
\hline
\end{tabular}

Source: Murakami (2009: 41).

Still, it has to be noted that the recent demise of the LDP is also due to its inability to deliver shared growth. The divided society model is rather fuzzy and does not depict a clear class structure of Japan. It is primarily a negative model in contrast to the general middle class model of shared growth. Abe's complete failure to establish political nationalism shows that shared economic growth is still the national project and social contract. Koizumi's structural reform agenda found supporters as it promised to lead back to shared growth. However, this promise was never realized by the LDP. Renewed growth led to rising company profits, but not to rising income and more job security among the population. The worldwide financial and economic crisis ruined the credibility of a market-oriented growth path in contemporary Japan. The DPJ, on the other hand, has basically promised in recent elections not only to be a valid alternative to the LDP, but to be the new champion of shared growth that will rebuild a more equal and all-inclusive society. This has made it an attractive option even among conservative voters.

In the rural-urban cleavage, a fundamental dealignment has occurred that was even more important for the change in power. Rising regional disparities, triggered by structural reforms, resulted in a fundamental weakening of rural support for the LDP. The defeats of the LDP are primarily due to the unchanged importance of rural electoral districts. Analysis of surveys as well as newspaper reports clearly show that the LDP can no longer count on a strong and unified support of the interest groups in Japan's rural areas (Fackler 6 August 2009; Karasaki 26 August 2009; Mori 2008; Yomiuri Shimbun 11 August 2007). Although the large majority of these interest groups did not switch their support to the DPJ, they are no longer unified support blocks for the LDP. Hence, the LDP has lost control of the countryside. Through its structural reform policy, it has alienated its former clientele groups that guaranteed 
its stay in power for over five decades. This loss of control is also due to a falling importance of rural interest groups (Mori 2008: 59-60). Not only the labor unions, as often discussed (e.g., Rebick 2005: 75-88), are confronted with less support among workers and a falling rate of unionization, but also other interest groups, including rural ones, have increasingly problems to unify and represent their constituencies.

\section{Concluding remarks}

The result of the two recent elections in 2007 and 2009 is a historic turning point in Japanese politics. Since the late 1940s, Japanese politics had been marked by a rural-urban division that was the central factor for the stay in power of the LDP and its predecessors. A social cleavage by social class was never fully institutionalized in Japanese politics. From the 1960s onward, the establishment of shared growth as the national project and social contract, and the ascension of the general middle class model, led to a further loss of importance of social class. However, in recent years, rising social inequalities and regional disparities have been intensively discussed and have resulted in the rise of a new model of Japan as a divided society. Although this new model has not led to an alignment of social cleavage by social class, it has resulted in a dealignment of the rural-urban division. Through this change the LDP has lost control of its old strongholds in rural areas. The divided society model is also directly connected to the perception of the end of shared growth that has played a crucial role in the crushing defeats of the LDP and the ascendance of the DPJ to power. The current LDP is neither a rural party, nor a party of shared growth. Koizumi seemed to introduce a new path to economic growth by structural reforms and deregulation, but large parts of Japanese society including rural areas saw themselves excluded from the return to economic growth between 2003 and 2008 . Furthermore, the neoliberal reform agenda has lost a lot of its credibility in view of the worldwide economic and financial crises since autumn 2008. While the successors of Koizumi were primarily a burden for the LDP, the DPJ under the leadership of Ozawa used this window of opportunity to present itself as a real alternative. It switched its policy agenda from a champion of structural reforms to a defender of social cohesion. More than ever before in the postwar period, Japanese politics is now characterized by nonpartisan voters. Still, the unchanged importance of shared growth as the national project and social contract means that the DPJ might only sustain its position of power if it is able to deliver shared growth - including rural areas - and to overcome the model of Japan as a divided society. 
In a comparative perspective of social cleavages, postwar Japan features several peculiarities. In contrast to nearly all Western democracies, a social cleavage by social class never fully developed in Japanese politics. This is mainly due to the partial organization of blue-collar workers into labor unions and the overshadowing of class politics by the debates on a new national project. The establishment of shared growth as the national project and the general middle class model further diminished the role of social class in voting behavior. The social cleavage between rural areas and urban centers was, however, a structural factor that deeply influenced the long hegemony of the LDP and Japan's political economy. In a general theoretical perspective on changing social cleavages, the alignment and dealignment of social cleavages in Japan are neither simple top-down processes nor one-way bottom-up processes. The changes in social cleavages are the result of a complex interplay between political elites, new models of Japan's social structure, and the resonance of these new models among the population. Regarding the turning point in the two recent elections, the DPJ under Ozawa's leadership was able to push and exploit the new divided society model, especially its arguments on rising regional disparities. Still, the divided society model as a new description of Japan's social structures found a deep resonance among the population as it matched everyday experiences. It was this resonance of the divided society model that opened up this window of opportunity for the DPJ. Moreover, it was actually part of the LDP and conservative establishment that had framed a new debate on social inequality by identifying egalitarianism as an obstacle to economic recovery. Hence, a combined approach on the complex interplay that leads to critical junctures seems most promising for a better understanding of social cleavages and their changes.

David Chiavacci (dachiava@zedat.fu-berlin.de) earned his Ph.D. in economic sociology at the University of Zurich and his habilitation in Japanese studies at the Free University of Berlin. His main research interests are economic sociology, political sociology, and knowledge sociology of contemporary Japan. Recent publications include a number of research articles in academic journals, including Asian Business \& Management, Japan Forum and Social Science Journal Japan.

\section{Notes}

1. The Komeitō is the political arm of the Sōka Gakkai, a lay Buddhist organization and the largest new religion in contemporary Japan. It was founded as political party in 1964 and became soon the third largest political party in Japan (Lee 1970).

2. For a comprehensive analysis of the development of the bias towards the countryside in Japanese politics since the 1960s, see Sugawara (2004). 
3. The Prime Minister in Japan has only the power to dissolve the Lower House, which is the more influential of the two chambers of the parliament.

4. Such amplifications are quite common in electoral systems like Japan's since 1993, in which single-seat districts are of crucial importance.

5. These simultaneous reforms led to reductions in general and specific subsidies of the central government to local governments and the transfer of tax authority from central government to local governments. However, the new income through direct taxes of local governments fell significantly short of the reduction in subsidies.

\section{References}

Asahi Shimbun. 27 June 1967. Susumu charya kaikyaka: 41-nendo kokumin seikatsu hakusho [Middle class consciousness advancing: White paper on national lifestyle 1966]. Evening edition. 1.

Asahi Shimbun. 27 January 2006. "Kakusa ga ronten" tsuyomaru: Kakuha kara "jakusha Hairyo o" ["The debate on inequality" is heating up: Politicians of all factions show "consideration for the weak"]. 3.

Babb, James. 2005. Making farmers conservative: Japanese farmers, land reform and socialism. Social Science Japan Journal 8 (2). 175-195.

Bartolini, Stefano \& Peter Mair. 1990. Identity, competition, and electoral availability: The stabilisation of European electorates 1885-1985. Cambridge: Cambridge University Press.

Bornschier, Simon. 2009. Cleavage politics in old and new democracies. Living Reviews in Democracy 1. http://democracy.livingreviews.org/index.php/lrd/article/view/lrd2009-6 (accessed 4 January 2010).

BSH (Bungei Shinsho Henshabu). 2000. Shinkaikyn shakai Nippon: Amerika-gata jakuniku-kyōshoku o yurusu no ka [New class society Japan: Do we want a law of the jungle like in the U.S.?]. Bungei Shunja 78 (6). 94-107.

BSH Bungei Shunju Henshabu (ed.). 2006. Ronso: Kakusa shakai [Controversy: Divided society]. Tokyo: Bungei Shunja.

Burniaux, Jean-Marc, Thai-Thang Dang, Douglas Fore, Michael Förster, Marco Mira d'Ércole \& Howard Oxley. 1998. Income distribution and poverty in selected OECD countries (OECD Economics Department Working Papers 189). Paris: OECD.

CAO (Cabinet Office). 2006a. Getsurei keizai hokoku nado ni kansuru kankei kakuryo kaigi shiryo (Ichigatsu) [Data for the cabinet meeting regarding the monthly economic report (January)]. Tokyo: CAO.

CAO. 2006b. Nenji keizai zaisei hokoku 2006 [Annual report on the Japanese economy and public finance 2006]. Tokyo: CAO.

Chiavacci, David. 2006a. Das japanische Gesellschaftsmodell in der Krise: Fazit und Versuch eines Ausblicks am Ende des verlorenen Jahrzehnts [Crisis of Japan's social model: Resume and possible prospects at the end of the lost decade]. In Manfred Pohl \& Iris Wieczorek (eds.), Japan 2006: Politik und Wirtschaft, 185220. Hamburg: Institut für Asienkunde.

Chiavacci, David. 2006b. The general middle class model under pressure: Mainstream Japan at a turning point? In Hede Helfrich, Melanie Zillekens \& Erich Hölter (eds.), Culture and development in Japan and Germany, 59-82. Münster: Daedalus Verlag.

Chiavacci, David. 2008. From class struggle to general middle-class society to divided society: Societal models of inequality in postwar Japan. Social Science Japan Journal 11 (1). 5-27.

CKH (Chūō Kōron Henshūbu) (ed.). 2001. Ronsō: Chūryū hōkai [Controversy: Collapse of the middle class]. Tokyo: Chno Koron Shinsha. 
Deegan-Krause, Kevin. 2007. New dimensions of political cleavage. In Russell J. Dalton \& Hans-Dieter Klingemann (eds.), The Oxford handbook of political behavior, 538-556. Oxford: Oxford University Press.

DeWit, Andrew \& Sven Steinmo. 2002. The political economy of taxes and redistribution in Japan. Social Science Japan Journal 5 (2). 159-178.

Elis, Volker \& Ralph Lützeler. 2008. Regionalentwicklung und Ungleichheit: Raumdisparitäten als Thema zur Prime Time - eine Einführung [Regional development and inequality: Spatial disparities as topic at primetime - an introduction]. Japanstudien 20), 15-33. Munich: Iudicium.

EPA (Economic Planning Agency, Keizai Kikakucho). 1964. Kokumin seikatsu hakusho, Showa 38-nendo: Shohi seikatsu no kosho to sono heijunka keiko [White paper on national lifestyle, 1963: Improvement of consumer life and its trend towards equalization]. Tokyo: Okurasho Insatsukyoku.

EPA. 1974. Kokumin seikatsu hakusho, Showa 49-nendo: Fuan no jidai no kokufuku no tame ni [White paper on national lifestyle, 1974: In order to overcome a period of insecurity]. Tokyo: Okurasho Insatsukyoku.

Fackler, Martin. 6 August 2009. Eroding rural base threatens to topple Japanese party's long rule. New York Times. A6.

Förster, Michael \& Marco Mira d'Ércole. 2005. Income distribution and poverty in OECD countries in the second half of the 1990s (OECD Social, Employment and Migration Working Papers 22). Paris: OECD.

Funaoka, Fumio. 2001. Nihon no shotoku nakusa ni tsuite no kentō [Study about Japan's income inequality]. Keizai Kenkya (Hitotsubashi Daigaku Keizai Kenkyajo) 52 (2). 117-131.

Galtung, Johan. 1971. Social structure, education structure and life long education: The case of Japan. In OECD (ed.), Reviews of national policies for education: Japan, 131-152. Paris: OECD.

Gordon, Andrew. 1993. Contests for the workplace. In Andrew Gordon (ed.), Postwar Japan as history, 373-394. Berkeley: University of California Press.

Hara, Junsuke (ed.). 2008. Hirogaru charya ishiki: 1971-1985 [Expanding middle class consciousness: 1971-1985]. Tokyo: Nihon Tosho Senta.

Hashimoto, Kenji. 2003. Class structure in contemporary Japan. Melbourne: Trans Pacific Press.

Hatoyama, Yukio. 2009. Watakushi no seiji tetsugaku: Sofu Ichirō ni mananda "yuai" to iu tatakai no hatajirushi [My political philosophy: The battle flag of "fraternité", learned from my grandfather, Ichirō]. Voice 381. 132-141.

Higuchi, Yoshio. 2008. Circumstances behind growing regional disparities in employment. Japan Labor Review 5 (1). 5-35.

Hüstebeck, Momoyo. 2009. Administrative und fiskalische Dezentralisierung in Japan: Instrumente zur Stärkung der japanischen lokalen Selbstverwaltung? [Administrative and fiscal decentralization in Japan: Instruments for strengthening Japan's local self-administration?]. In Gesine Foljanty-Jost (ed.), Kommunalreform in Deutschland und Japan: Ökonomisierung und Demokratisierung in vergleichender Perspektive, 31-58. Wiesbaden: VS Verlag für Sozialwissenschaften.

Imada, Takatoshi. 1989. Shakai kaiso to seiji [Social stratification and politics]. Tokyo: Tōkyō Daigaku Shuppankai.

Imada, Takatoshi. 1999. Byōdō shakai no shinwa o koete: Sengo Nihon no sangyōka to shakai kaisō [Beyond the myth of an egalitarian society: Industrialization and social stratification in postwar Japan]. Nihon Rōdō Kenkyū Zasshi 41 (10). 2-16.

Imai, Ryōsuke \& Ikuo Kabashima. 2008. The LDP's defeat in crucial single-seat constituencies of the 2007 Upper House election. Social Science Japan Journal 11 (2). $277-293$. 
Ishida, Hirohide. 1963. Hoshu seito no bijon [Vision of a conservative party]. Chao Kōron 78 (1). 88-97.

Ishida, Hiroshi. 2008. Sedaikan idō e no saizon bunseki apurōchi [Survival analysis of the intergenerational mobility]. In Tsutomu Watanabe (ed.), Sedaikan idō to seidainai idō (SSM chōsa shirīzu 3) [Intergenerational and intragenerational mobility (The 2005 SSM research series 3)], 55-74. Sendai: The SSM Research Committee.

Ishida, Hiroshi \& David H. Slater. 2009. Social class in Japan. In Hiroshi Ishida \& David H. Slater (eds.), Social class in contemporary Japan: Structures, sorting, and strategies, 1-29. London: Routledge.

JILPT (The Japan Institute for Labour Policy and Training, Rodo Seisaku Kenkya Kenshū Kikō). 2008. Chi'iki koyō seisaku to chi'ikibetsu jūgyyōinsū no sui'i (JILPT shiryō shirizu 38) [Regional labor policy and the change in the number of workers in each region (JILPT data series 38)]. Tokyo: JILPT.

Kaihara, Hiroshi. 2008. Japan's political economy and Koizumi's structural reform: A rise and fall of neoclassical economic reform in Japan. East Asia 25 (4). 389-405.

Kaneko, Masaru. 27 September 2005. Seiji no baburu: Jinsei no iyoku hikui wakamono o yowaseta "Koizumi gekijō" [Bubble politics: "The Koizumi theater" intoxicated young people with low aspirations in life]. Asahi Shimbun. 14.

Karasaki, Taro. 26 August 2009. LDP heavyweights on back foot in stronghold districts. The Asahi Shimbun. http://www.asahi.com/english/Herald-asahi/ TKY200908260031.html (accessed 28 August 2009).

Kawato, Sadafumi, Takashi Yoshino, Hiroshi Hirano \& Junko Katō. 2001. Gendai no seitō to senkyo [Contemporary political parties and elections]. Tokyo: Yūhikaku.

Knutsen, Oddbjørn. 2007. The decline of social class? In Russell J. Dalton \& HansDieter Klingemann (eds.), The Oxford handbook of political behavior, 457-480. Oxford: Oxford University Press.

Kohno, Masaru. 2001. Why didn't the Japanese socialists moderate their policies much earlier to become a viable alternative to the liberal democratic party? In Bernard Grofman (ed.), Political science as puzzle solving, 65-84. Ann Arbor: University of Michigan Press.

Krauss, Ellis S. \& Robert Pekkanen. 2008. Reforming the liberal democratic party. In Sherry L. Martin \& Gill Steel (eds.), Democratic reform in Japan: Assessing the impact, 11-37. Boulder: Lynne Rienner.

KSK (Keizai Senryaku Kaigi). 1999. Nihon keizai saisei e no senryaku [Strategy for a rebuilding of Japan's economy]. Tokyo: Keizai Senryaku Kaigi.

Lee, Jooinn. 1970. Komeito: Sokagakkai-Ism in Japanese Politics. Asian Survey 10 (6). $501-518$.

Lipset, Seymour M. \& Stein Rokkan. 1967. Cleavage structures, party systems, and voter alignments: An introduction. In Seymour M. Lipset \& Stein Rokkan (eds.), Party systems and voter alignments: Cross-national perspectives, 1-64. New York: The Free Press.

Maeda, Yukio. 2006. Saikin no Jiji yoron chōsa ni okeru seitō shijiritsu to naikaku shijiritsu [Support of political parties and of the cabinet in recent Jiji surveys]. Ch̄̄o Chōsahō 581. 1-9. http://www.crs.or.jp/58111.htm (accessed 4 January 2010).

Masumi, Junnosuke. 1985. Postwar politics in Japan, 1945-1955. Berkeley: Institute of East Asian Studies, University of California.

MIC (Ministry of Internal Affairs and Communications). 2005. Katei chōsa nenpō [Yearbook of the survey of household economy]. Tokyo: MIC.

MIC. 2009. Statistical handbook of Japan 2009. Tokyo: MIC.

Miura, Atsushi. 2005. Karyã shakai: Aratana kaisō shädan no shutsugen [Underclass society: The appearance of a new social class]. Tokyo: Kōbunsha. 
Miyano, Masaru. 2000. Kaiso to seiji [Social class and politics]. In Kenji Kosaka (ed.), Nihon no kaisō shisutemu 6: Kaisō shakai kara atarashii shimin shakai e [Stratification system in Japan 6: From a stratified society to a new civil society], 53-71. Tokyo: Tōkyō Daigaku Shuppankai.

Mori, Hiroki. 2008. Senkyo katei ni okeru rieki shudan no dōkō: 2005-nen shūgi'insen, 2007-nen sangi'insen no bunseki to JIGS2 chōsa no hōkoku [Interest group's activities in the electoral process: Analysis of the 2005 Lower House election and 2007 Upper House election and report on the JIGS2 survey]. Doshisha Hogaku 60 (5). $45-77$.

Mulgan, Aurelia George. 2005. Japan's interventionist state: Bringing agriculture back in. Japanese Journal of Political Science 6 (1). 29-61.

Murakami, Hiroshi. 2009. The changing party system in Japan 1993-2007: More competition and limited convergence. Ritsumeikan Law Review 26. 27-48.

Murakami, Yasusuke. 20 May 1977. Shinchūkan kaisō no genjitsusei [Reality of the new middle class]. Asahi Shimbun (evening edition). 7.

Murakami, Yasusuke. 1984. Shinchūkan daishū no jidai: Sengo Nihon no kaibōgaku [The era of a new mass middle class: Anatomy of postwar Japan]. Tokyo: Chnō Kōronsha.

Murao, Takashi \& Shigeki Kurokawa. 20 February 2007. Disparity policy drafted hastily: Government's new strategy seen as response opposition criticism. The Daily Yomiuri. 3.

Nakatani, Iwao. 1996. Nihon keizai no rekishiteki tenkan [The historic turning point of the Japanese economy]. Tokyo: Tōyō Keizai Shinpōsha.

Nakatani, Iwao. 1997. A design for transforming the Japanese economy. The Journal of Japanese Studies 23 (2). 399-417.

Naoi, Michiko \& Akira Tokuyasu. 1990. Seiji shiji ishiki: 1985-nen made Jimintō shijiritsu wa naze heranakatta ka [Attitudes of political support: Why has the support rate of the LDP not decreased up to 1985?]. In Junsuke Hara (ed.), Gendai Nihon no kaiso kozo 2: Kaiso ishiki to dotai, 149-172. Tokyo: Tokyo Daigaku Shuppankai.

OECD (Organization of Economic Co-operation and Development). 2006. Economic survey of Japan 2006. Paris: OECD.

Ōta, Kiyoshi. 2006. Nihon no chinkin kakusa wa chīsai no ka (ESRI Discussion Paper 172) [Wage disparity in Japan: A cross-country comparison (ESRI Discussion Paper 172)]. Tokyo: Economic and Social Research Institute (ESRI), Cabinet Office.

Otake, Fumio. 2000. 90-nendai no shotoku kakusa [Income inequality in the 1990s]. Nihon Rōdō Kenkyū Zasshi 42 (7). 2-11.

Ōtake, Fumio. 2005. Nihon no fubyōdō: Kakusa shakai no gensō to mirai [Japan's inequality: The illusion and future of a divided society]. Tokyo: Nihon Keizai Shinbunsha.

Pyle, Kenneth B. 1992. The Japanese question: Power and purpose in a new era. Washington: The AEI Press.

Rebick, Marcus. 2005. The Japanese employment system: Adapting to a new economic environment. Oxford: Oxford University Press.

Reischauer, Edwin O. 1977. The Japanese. Cambridge: Harvard University Press.

Sano, Shin'ichi. 2006. Rupo kasō shakai: Kaikaku ni suterareta kazoku o miyo [Underclass society report: Look at the families that have been abandoned by the reforms]. Bungei Shunjū 84 (5). 94-109.

Satō, Toshiki. 2000. Fubyōdō shakai Nihon: Sayōnara sōchūryū [Unequal Japanese society: Goodbye general middle class]. Tokyo: Chūō Kōron Shinsha.

Sawyer, Malcolm C. 1976. Income distribution in OECD countries. In OECD (ed.), OECD Economic outlook occasional studies, 3-36. Paris: OECD. 
Scheiner, Ethan. 2006. Democracy without competition in Japan: Opposition failure in a one-party dominant state. New York: Cambridge University Press.

Schoppa, Leonard. 2001. Locating the LDP and Koizumi in policy space: A party system ripe for realignment. Social Science Japan Journal 22. 9-15.

Seiyama, Kazuo. 2000. Charya hokai wa "monogatari" ni suginai [The collapse of the middle class is not more than a "fairy tale"]. Chao Koron 115 (12). 84-91.

Steel, Gill. 2008. Policy preferences and party platforms: What voters want vs. what voters get. In Sherry L. Martin \& Gill Steel (eds.), Democratic reform in Japan: Assessing the impact, 81-99. Boulder: Lynne Rienner.

Sugawara, Taku. 2004. Nihon seiji ni okeru noson baiasu [Bias towards farm villages in Japanese politics]. Nihon no Seiji Kenkya 1 (1). 53-86.

Tachibanaki, Toshiaki. 1998. Nihon no keizai kakusa: Shotoku to shisan kara kangaeru [Economic inequality in Japan: Income and wealth analyzed]. Tokyo: Iwanami Shinsho.

The Daily Yomiuri. 27 January 2006. Politicians worry over widening rich-poor chasm. 3.

The Daily Yomiuri. 3 September 2006. Rich-poor gap focus of LDP poll: LDP leadership candidates offering various approaches to reform. 3.

Vogel, Ezra F. 1979. Japan as number one: Lessons for America. Cambridge: Harvard University Press.

Vogel, Ezra F. 1986. Pax Nipponica? Foreign Affairs 64 (4). $752-767$.

Watanuki, Joji. 1967. Patterns of politics in present-day Japan. In Seymour M. Lipset \& Stein Rokkan (eds.), Party systems and voter alignments: Cross-national perspectives, 447-466. New York: The Free Press.

Yamada, Masahiko. 2004. Kibo kakusa shakai: "Makegumi” no zetsubokan ga Nihon $o$ hikisaku [Divided society of hope: The despair of the "loser group" is splitting Japan]. Tokyo: Chikuma Shobo.

Yomiuri Shimbun. 28 July 1964. Kya wari ga charya ishiki: "Kokumin seikatsu" no seifu yoron chosa $[90$ percent identifying themselves with the middle class: Governmental public opinion poll "people's lifestyle"]. Evening edition. 2.

Yomiuri Shimbun. 11 August 2007. Minshu yakushin, mutoha ga ato'oshi: Kotoshi, choson ni mo shinto [DPJ taking the lead thanks to unaffiliated voters: DPJ also penetrating small cities and villages]. 11.

Yoneda, Yukihiro. 2008. Seiji shiji kodo no henka: 1995-nen to 2005-nen no jiten aida hikaku [The transition of party support: A time-series comparison between 1995 and 2005]. In Gaku Doba (ed.), Kokyosei to kakusa (SSM chosa shirtzu 7) [Publicness and economic inequality in contemporary Japan (SSM research series 7)], 137-154. Sendai: The SSM Research Committee. 